\title{
Farmer Practices and Risk of Water Contamination by Pesticides Used in Vegetable Cropping in Ouagadougou, Burkina Faso
}

\author{
Sylvain Ilboudo ${ }^{1,2, *}$, Sountong-Noma Faizatou Sorgho ${ }^{3}$, Paul Windinpsidi Savadogo ${ }^{2,3,4}$, \\ Geoffroy Gueswindé Ouedraogo ${ }^{1}$, Félix dit Bondo Kini ${ }^{1}$, Sylvin Ouedraogo ${ }^{1}$ \\ ${ }^{1}$ Institute of Research in Health Science, (IRSS/CNRST), Ouagadougou, Burkina Faso \\ ${ }^{2}$ Joint International Research Unit - Environment, Health and Society (UMI 3189, ESS) CNRST/CNRS/UCAD/UGB/USTTB, Ouagadougou, \\ Burkina Faso \\ ${ }^{3}$ Institute of Environmental Engineering and Sustainable Development (IGEDD), Joseph KI-ZERBO University, Ouagadougou, Burkina Faso \\ ${ }^{4}$ Institute of Environment and Agricultural Research (INERA/CNRST), Ouagadougou, Burkina Faso
}

Email address:

sylvain.ilboudo@gmail.com (S. Ilboudo)

${ }^{*}$ Corresponding author

\section{To cite this article:}

Sylvain Ilboudo, Sountong-Noma Faizatou Sorgho, Paul Windinpsidi Savadogo, Geoffroy Gueswindé Ouedraogo, Félix dit Bondo Kini, Sylvin Ouedraogo. Farmer Practices and Risk of Water Contamination by Pesticides Used in Vegetable Cropping in Ouagadougou, Burkina Faso. International Journal of Environmental Monitoring and Analysis. Vol. 7, No. 6, 2019, pp. 128-136. doi: 10.11648/j.ijema.20190706.13

Received: November 14, 2019; Accepted: December 5, 2019; Published: December 11, 2019

\begin{abstract}
Vegetables are grown world-wide in almost 200 countries, but they are regularly subject to pest pressure. To cope with the multiple pests, farmers resort to pesticides whose use in developing countries carries health and environmental risks. This study aimed to investigate the practices of vegetable farmers from Ouagadougou when using pesticides, and to examine the potential for contamination of ground and surface water. Based on the use of questionnaires and field observations, this study investigated farmers' practices on vegetable pest management using pesticides. The physicochemical properties of the active ingredients of pesticide were analysed, and Goss and GUS algorithms were applied to estimate the risk of surface and ground water contamination, respectively. The majority of producers were male $(58 \%)$, illiterate $(80 \%)$ and use pesticide in their vegetable crops $(97.72 \%)$. The products used by the farmers in the study areas were insecticides (28), herbicides (5), fungicides (1), and nematicide (1), altough more than $50 \%$ of these pesticides were registered for the treatment of cotton crops but not for vegetables. Depending on the crop, $88 \%$ of the farmers applied pesticides up to 5 times or more per cropping season. Among active ingredients from pesticides used by farmers, eight are highly solubles, nine are readily degradables, six are moderately mobiles, and five are imobiles. Five have high potential to contaminate surface water while one has high potential to contaminate ground water. These results can be used for the development of tool to predict water contamination by pesticides in pest management by vegetable farmers. This could contribute to the reinforcement of pesticides policy for advance their health, environmental and economic consequences.
\end{abstract}

Keywords: Vegetable, Farmer Practices, Pesticides, Goss Algorythm, GUS Index, Water Contamination

\section{Introduction}

Vegetables are grown world-wide in almost 200 countries. They are vital to the general good health of human beings, providing essential vitamins and minerals, dietary fiber and phytochemicals, and reducing risk from dangerous diseases and other medical conditions [1]. In many parts of
sub-Saharan Africa, indigenous vegetables have added important nutritional value to the diets of locals for hundreds of years. Beyond its nutritional interest, the economic importance of vegetables pushes the populations of cities and suburbs of developing countries to turn to urban and peri-urban agriculture, especially vegetable production which contributes to the reduction of unemployment, fight against poverty and food insecurity in households with limited 
resources [2]. Vegetable remains the most popular agricultural activity in the main cities of Burkina Faso, with an increase of areas intended for vegetable production in the order of $225 \%$ from 1996 to 2009 [3].

Despite its contribution to the socio-economic development of the city, the sector faces many challenges including land pressure, organizational and regulatory difficulties and pest pressure. Crop losses due to damage caused by pests, diseases, nematodes and weeds are a major agricultural problem for producers [2]. In 2010, losses attributed to pathogens, insects, virus, and weeds in six major crops (rice, wheat, maize, potatoes, soybean, and cotton seeds) amounted to US\$16.16 billion in Africa [4].

Up to date, pesticides constitute the key control tactics for management of pests and diseases and the productivity of crops depends on their effective control [5]. Pesticides are a class of chemicals designed to kill pests (rodents, insects, or plants) that may affect agricultural crops. In the area of vegetable production, about 59 to $100 \%$ of vegetable farmers periodically apply pesticides against pests $[6,7]$. However, controversy exists over the global dependence on such agents, given their excessive use: misuse, their volatility, long-distance transport and eventual environmental contamination in colder climates [8]. Furthermore, pesticides are poisons and, unfortunately, they can harm more than just the "pests" at which they are targeted. They are toxic, and exposure to pesticides can cause a number of health and environment effects. The unsafe and indiscriminate use of pesticides in agriculture represents a major hazard to the environment and human health [9]. A growing number of studies from some zones of Burkina Faso have shown anarchic use of plant protection products and contamination of surface and groundwater in areas of pesticides use $[7,10$, $11]$.

Although misuses of pesticide increase environmental risks in high population-density areas, few papers have been published on the environmental impacts of pesticide use in tropical areas and particularly in Africa [4]. The aim of this paper was to understand farmers' pest management practices in vegetable crops in Ouagadougou, and to derive some implications for pest management in future. Through the study of cropping practices among vegetable farmers in Ouagadougou and characterization of pesticides used, this work is aimed to provide a better understanding of the potential risk of pollution of ground and surface water.

\section{Materials and Methods}

\subsection{Study Area}

The study took place in Ouagadougou (Figure 1), town located in the centre of Burkina Faso (12 $20^{\prime}$ and $12^{\circ} 26^{\prime}$ north latitude and $1^{\circ} 28$ and $1^{\circ} 36^{\prime}$ west longitude). Ouagadougou has Sudano-Sahelian climate characterized by alternating between a short rainy season lasting from May to September, and a long dry season from October to April [12]. The soils are leached, shallow and nutrient-poor tropical ferruginous types. They are formed on sandy, sandy-clayey or clayey materials [13]. The rainwater of the city of Ouagadougou is drained towards three main dams through topographic depressions arranged in canals. The city of Ouagadougou is experiencing a strong unprecedented demographic explosion, due to the rural exodus and to immigrants who are seeking well-being [14]. This situation leads to an extension and an increase in the city's food needs, at the origin of the spontaneous development of urban agriculture, including market gardening [3]. Agricultural activities in and around the city of Ouagadougou focus on cereals cultivation, market gardening, forestry (nursery and florists) and livestock. An inventory of agricultural sites reveals 71 vegetable production sites generally located in shallows, along rivers, allotments, non-construction areas, and undeveloped areas on the outskirts of the city $[15,3]$. Based on the approach used by Nguyen et al. [16], the sites were selected for the survey based on the importance and scale of vegetable production, agro-ecology, types of crops produced, and accessibility.

\subsection{Questionnaire Development and Delivery for Farmers Practice and Risk}

Exploratory field visits on the study area helped to identify and appreciate the importance of vegetable farm sites. A sample of 88 male and female vegetable producers from the selected sites were included systematically in the study, after their free and informed consent. Diagnostic surveys, formal interviews, and field observations were used to gather information on farmers' knowledge of pesticides and safety practices. The questionnaires were individually administered to producers. The direct observations focused on the type of soil, the distance between the treated surface and the water body, the slope, the presence of a buffer zone and the behavior of farmers in their place of work, particularly with regard to transport, preparation, and application of pesticides and the management of leftovers and empty packaging of pesticides.

The questionnaire was designed in french and translated into the local language that are understood by majority of the farmers. The questionnaire, inspired from Jallow et al. [9], included closed and open-ended questions, and was pre-tested by randomly interviewing twenty farmers not included in this study. The questionnaire contained three main sections. The first section one was designed to collect information on personal characteristics of the farmers including age, educational level, and years of farming experience. The second section focused on collecting information on farmers' level of awareness of pesticide laws and regulations, and knowledge and understanding of pesticides with respect to the environmental and human health. The third section included questions regarding pesticide handling and safety practices including reading and following label instructions, storing and disposing of pesticides and empty containers, and use of PPE and other protective practices during and after pesticide application. 


\subsection{Prediction of the Risk of Ground and Surface Water Contamination with Pesticides}

\subsubsection{Physico-chemical Properties and Environmental Fate of Pesticides}

When a pesticide is applied in the environment, it becomes distributed among the four major compartments: water, air, soil, and biota. The fraction of the chemical that will move into each compartment is governed in part by the physicochemical properties of that chemical. The transfer of the pesticide from one compartment to another depend to processes such as volatilization, drift, retention, leaching and runoff, to which is added the degradation process which also plays an important role in environmental contamination. For the purpose of the study, the main pesticide properties as solubility in water at $20^{\circ} \mathrm{C}$, coefficient of adsorption in organic matter (Koc), and typical half-life in soil $\left(\mathrm{DT}_{50}\right)$ [17].

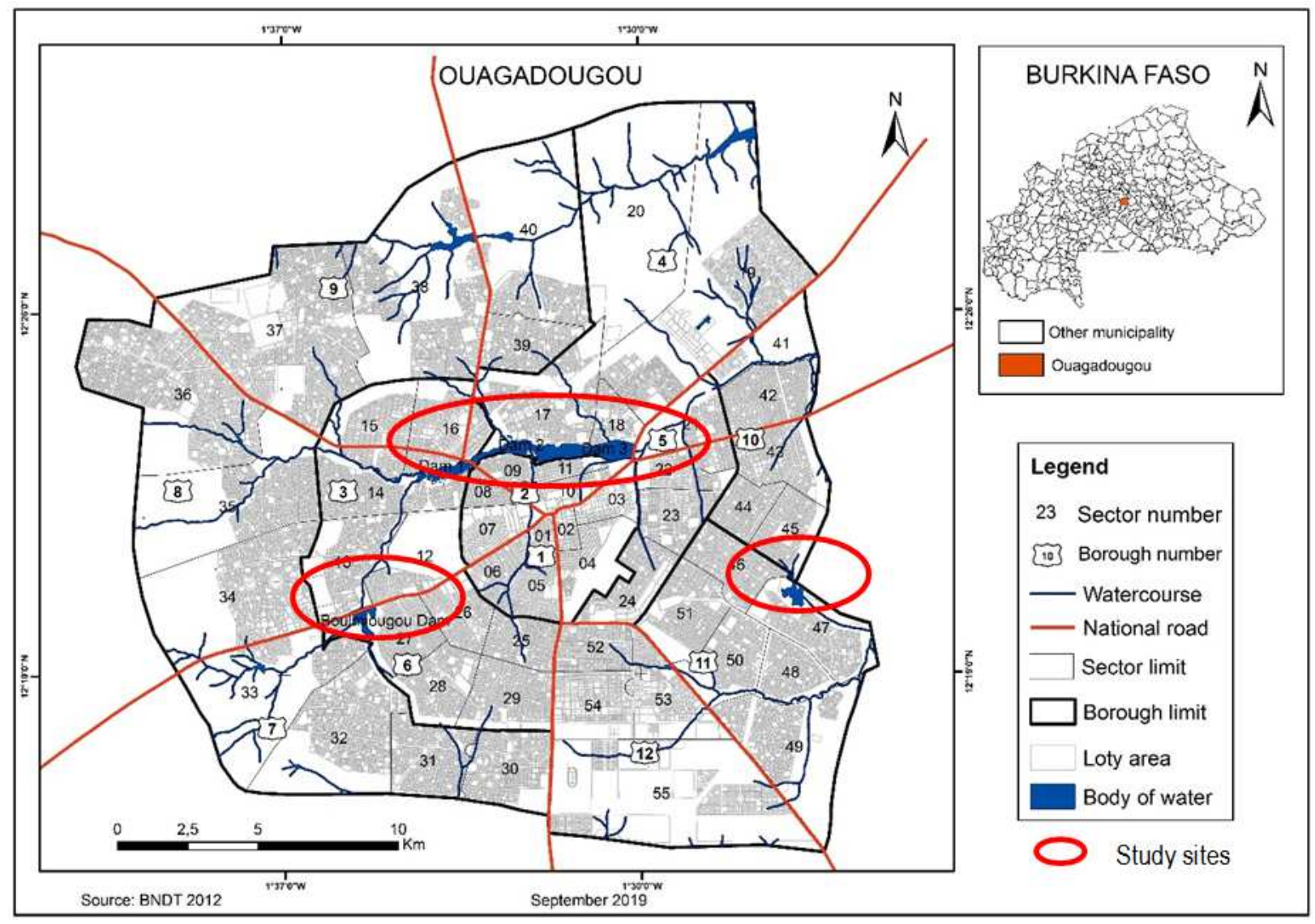

Figure 1. Municipality of Ouagadougou with its hydrographic network sheltering the study sites.

Solubility is a measure of the amount of chemical that can dissolve in water. Pesticide solubility is an important factor in waste disposal. Solubility can indicate the maximum amount of pesticide in solution in any accidentally contaminated water.

The solubility of a compound in water is given in $\mathrm{mg} / \mathrm{L}$ at $20^{\circ} \mathrm{C}$. According to the values taken by this parameter, compound will be considered Not soluble $(<0.10)$; Slightly soluble (0.1-1); Moderately soluble (1-10); Readily soluble (10-100); Highly soluble ( $>100)$.

The partition coefficient Koc is defined as the ratio of pesticide concentration in a state of sorption (i.e. adhered to soil particles) and the solution phase (i.e. dissolved in the soil water). Thus, for a given amount of pesticide, the smaller the Koc value, the greater the concentration of the pesticide in solution. Pesticides with a small Koc value are more likely to leach into groundwater than those with a large Koc value. Because of the large range of Koc values, the logarithm of Koc is already used. Based on chemical Log Koc, the values considered for each parameter are: Highly mobile $(<1)$; Mobile (1-2); Moderately mobile (2-3); Slightly mobile (3-4); Hardly mobile (4-5); Immobile (>5).

The organic compounds in soil undergo a lot of changes. Most pesticides break down or degrade over time as a result of several chemical and microbiological reactions in soils. Some are broken down by sunlight. The value of the degradation is given by half-life $\mathrm{DT}_{50}$. Half-life $\mathrm{DT}_{50}$ is a measure of the amount of time (in days) it takes for 50 percent of the parent compound to disappear from soil or water by transformation. The important degradation processes are biological processes (biodegradation) and physicochemical processes (hydrolysis, photolysis, etc.). The values considered for each parameter are: Readily degradable $\left(\mathrm{DT}_{50}<20\right)$; Fairly degradable (20-60); Slightly degradable (60-180); Very slightly degradable or persistent $\left(\mathrm{DT}_{50}>180\right)$.

\subsubsection{Evaluation of Surface Water Contamination Potential}

The evaluation of pesticide potential to reach the surface 
water was performed in application of criterion proposed by Goss [18] as described by Kortekamp [19]. This criterion considers the half-life $\left(\mathrm{DT}_{50}\right)$ of the chemical in soil, its water solubility and the soil sorption coefficient (Koc). According to this criterion, the active ingredients of pesticides are divided into six groups: High Sediment-Transport Runoff Potential (HSTRP); Medium Sediment-Transport Runoff Potential
(MSTRP); Low Sediment-Transport Runoff Potential (LSTRP); High Water-Phase-Transport Runoff Potential (HWTRP); Medium Water-Phase-Transport Runoff Potential (MWTRP); Low Water-Phase-Transport Runoff Potential (LWTRP). The values considered for each parameter are presented in table 1.

Table 1. Goss'algorithm for evaluating a pesticide's contamination potential in surface water.

\begin{tabular}{|c|c|c|c|}
\hline \multirow{2}{*}{ Transportation } & \multicolumn{3}{|l|}{ Contamination potential } \\
\hline & High & Low & Medium \\
\hline \multirow{6}{*}{ Associated to soil (AD) } & $\mathrm{DT}_{50} \geqslant 40$ and $\mathrm{K}_{\mathrm{oc}} \geq 100$ & If $\mathrm{DT}_{50} \leq 1$ & \\
\hline & or & or & \\
\hline & $\mathrm{DT}_{50} \geq 40$ and $\mathrm{K}_{\mathrm{oc}} \geq 500$ and solubility $\leq 0.5$ & $\begin{array}{l}\text { If } \mathrm{DT}_{50} \leq 2 \text { and } \mathrm{K}_{\mathrm{oc}} \leq 500 \\
\text { or }\end{array}$ & \\
\hline & & $\begin{array}{l}\text { If If } \mathrm{DT}_{50} \leq 4 \text { and } \mathrm{K}_{\mathrm{oc}} \leq 900 \text { solubility } \geq 0.5 \\
\text { or }\end{array}$ & All others \\
\hline & & $\begin{array}{l}\text { If If } \mathrm{DT}_{50} \leq 40 \text { and } \mathrm{K}_{\mathrm{oc}} \leq 500 \text { solubility } \geq 0.5 \\
\text { or }\end{array}$ & \\
\hline & $\begin{array}{l}\text { If solubility } \geq 1 \text { and } \mathrm{DT}_{50} \geq 35 \text { and } \mathrm{K}_{\mathrm{oc}} \leq 100000 \\
\text { or }\end{array}$ & $\begin{array}{l}\text { If If } \mathrm{DT}_{50} \leq 4 \text { and } \mathrm{K}_{\mathrm{oc}} \leq 900 \text { solubility } \geq 2 \\
\text { If } \mathrm{K}_{\mathrm{oc}} \geq 100000 \\
\text { or }\end{array}$ & \\
\hline Dissolved in water & If solubility $\geq 10$ and solubility $\leq 100$ and $K_{o c} \leq 700$ & $\begin{array}{l}\text { If } \mathrm{K}_{\mathrm{oc}} \geq 1000 \text { and } \mathrm{DT}_{50} \leq 1 \\
\text { or } \\
\text { If solubility }<0.5 \text { and } \mathrm{DT}_{5_{0}}<35\end{array}$ & All others \\
\hline
\end{tabular}

Source: $[18,20]$.

\subsubsection{Evaluation of Ground Water Contamination Potential}

Table 2. Algorythm for determination of GUS indexes.

\begin{tabular}{llll}
\hline \multirow{2}{*}{ Equation } & Classification & & \\
\cline { 2 - 4 } & High & Low & Very low \\
\hline $\mathrm{GUS}=\log \left(\mathrm{DT}_{50}\right) \times\left(4-\log \left(\mathrm{K}_{\mathrm{oc}}\right)(\right.$ equation 1$)$ & $\geq 2.8$ & $\leq 1.8$ & $<$ or solubility $<1$ and $\mathrm{DT}_{50}<1$ \\
\hline
\end{tabular}

Source : $[18,20]$.

The potential of pesticides to contaminate groundwater was estimated through the leaching potential index determination following the Groundwater Ubiquity Score (GUS) methodology [21]. The GUS index is based on the partition coefficient between soil organic carbon and water-sorption coefficient (Koc) and the half-life $\left(\mathrm{DT}_{50}\right)$ in soil for each pesticide active ingredient. The GUS index was calculated according to equation 1 [20].

\subsection{Data Analysis}

Survey data were coded, entered, and then analyzed using EpiData V2.2.3.187. Descriptive results were expressed as frequencies and percentages. The Excel software was employed to treat the data and to apply the Goss and Gustafson algorithms. The physicochemical properties of each active ingredient were extracted from the website of the International Union of Pure and Applied Chemistry (https://sitem.herts.ac.uk/aeru/iupac/).

\section{Results and Discussion}

\subsection{Social and Professional Characteristics of the FARMERS}

The results of the survey (table 3 ) describe the social and professional characteristics of the farmers. The majority (58) of the farmers interviewed were male. The average age of producers is about 42 years, with $51 \%$ aving up to 40 years. The majority of producers $(80 \%)$ were illiterate or had only primary school education (10\%). Oluwole and Cheke [22] in a previous study was found that the majority of the farmers who were either illiterate or with only primary school education depended on explanations from other farmers and/or pesticide suppliers. These results suggest that no more than $10 \%$ of vegetable farmers in Ouagadougou are able to read the label instructions for proper use of pesticides. Only $37 \%$ of survey respondents received training related to pesticide safety or safe and effective pesticide application. The lack of training on pesticides use is commonly reported by several authors [7, $6,11]$. The lack of training and the illiteracy of the study population may encourage bad practices including non-compliance with doses and schedules of treatment, with risks of environmental contamination.

Table 3. Social and professional characterizations of vegetable farmers.

\begin{tabular}{|c|c|c|}
\hline Characteristics & $N(n=88)$ & $\%$ \\
\hline \multicolumn{3}{|l|}{ Gender } \\
\hline Male & 51 & 58 \\
\hline Female & 37 & 42 \\
\hline \multicolumn{3}{|c|}{ Member of an association } \\
\hline Yes & 29 & 33 \\
\hline
\end{tabular}




\begin{tabular}{cll}
\hline Characteristics & $\mathbf{N}(\mathbf{n}=\mathbf{8 8})$ & $\mathbf{\%}$ \\
\hline No & 25 & 28 \\
NR & 46 & 39 \\
Age groups & & \\
{$[20-30]$} & 16 & 18 \\
{$[31-40]$} & 28 & 32 \\
{$[41-50]$} & 23 & 26 \\
{$[51-60]$} & 18 & 21 \\
{$[61-70]$} & 3 & 3 \\
Education level & & \\
Illiterate & 70 & 80 \\
Primary school & 9 & 10 \\
Secondary school & 9 & 10 \\
Professional training on pesticide use & & \\
Yes & 32 & 37 \\
No & 56 & 63 \\
\hline
\end{tabular}

\subsection{Vegetable Produced by Farmers of Ouagadougou Town}

According to the results of the survey, a very large diversity of crops are produced in the study area. The main vegetable crops identified in the study are long cycle (cultivation duration of two to three months before harvest) and short cycle (cultivation duration of one to two weeks before harvest) crops. Short-cycle vegetables identified include Spinacia oleracea (Spinach), Apium graveolens (Celery), Amaranthus hibridicus (Amaranth), and Petroselium crispum (Parsley). Long-cycle vegetables include Lactuca sativa $\mathrm{L}$. Var. battavia (Lettuce), Brassica oleracea L. Var. capitata (Cabbage), Cucumis sativas (Cucumber), Phaseolus vulgaris (Green beans), Piscum sativum (Peas), Piscum sativum (Peas), Fragaria sp (Strawberry), Capsicum frutescens (Pepper), Capsicum annum L. (Sweet peppers), Daucus carota (Carrot), Brassica napus (Turnip), Beta vulgaris (Beet), Allium porrum (Leek), Raphanus napus (Radish), Solanum tuberosum (Potato), Allium cepa (Onion), Hibiscus sabdariffa (Sorrel), and Solanum melongena L. (Eggplant). This diversity had already been reported by Nabie in 2018 [15]. Otherwise, the respondents indicated that each type of crop is exploited for a fixed period of the year.

\subsection{Pesticides Commonly Used by Farmers and Practices}

The results showed a great diversity of pesticides used for vegetable production. Table 4 summarizes information about pesticides used, their active ingredient (s), chemical familly, WHO classification according to their toxicity, physical appearance, crop on which it is registered, and their registration status. 35 formulations containing 17 active substances have been identified. Although formulations were in the majority (65.71\%) registered by the CSP (Comité Sahélien des Pesticides), almost the half of them (17/35) were registered for cotton crops. Only 13 out of 35 were registered for use on vegetables. Such misuse of pesticides appears to be widespread practice among farmers, especially in developing countries as reported by several studies $[7,11,6,23]$. In addition to asking the residue problem in the food chain, such practices are potentially polluting for water, as the cotton farms agropedological situation is different from that of vegetable crops field.

Mostly (97.72\%), vegetable producers in Ouagadougou make pesticide use in their production operations. The frequency of pesticides use varied by crop. The crops most subjected to treatment are Lettuce, Cabbage, Amaranth, Sorrel, and Eggplant. Some farmers report that cabbage must undergo 24 insecticide treatments during their production cycle. The main practices of vegetable farmers of Ouagadougou are reported in table 5. The majority of the respondents uses pesticides every week for pests managment on vegetable production. Similar results were found by Ngowi et al. [24] who had noted that more than $15 \%$ of farmers in the Northern Tanzania reported applying pesticides 16 times or more per cropping season. This recurrent use of pesticides is justified by the constant pressure of pests targeting these crops [7]. Also, producers seem to be inclined to meet the demands of consumers who want high quality products. Vegetable producers tended to use more pesticides in order to preserve their crops or vegetables to pest alteration for more economic benefits [25]. The important use of pesticides may result in frequent release of pesticides in environnement with potential contamination of soils and water.

Producers acquire their pesticides mainly from the market $(46 \%)$ and retailers $(37 \%)$. These pasticides are delivered to producers in reconditioned form. In these circumstances, it is obvious that there is no label accompanying the delivery of these products, and there is therefore no possibility of having instructions on the proper use of plant protection products. In general, it is the reseller who advises the producer on the choice of pesticides and how these products should be used. However, as also reported by Toe et al. [11], resellers do not have training to give such advice. From this observation, we can admit that the packaging proposed by pesticide manufacturers is not adapted to the farmers needs. Indeed, they have small areas and it is neither practical nor economic for the small farmers to pay a whole box of a pesticide and use only a small part.

The majority of producers ( $86 \%$ ) use backpack sprayers for pesticide application. However, a minority of them use watering cans and buckets with tree branches to spray their crops. These practices are highly polluting for the environment. It is not possible to meet the doses under these conditions, and the pesticide is not uniformly distributed on the crop. The use of inappropriate instruments for the application of pesticides has often been reported. Thus, Tarnagda et al. [26] reported the use of branches of trees for pesticides spray in Ouagadougou.

The vegetable farmers irrigate their crops by drawing water from dams $(69 \%)$ or wells $(59 \%)$, or both. $34 \%$ of the fields are within 10 meters of the water body, and only $11 \%$ of the fields are located more than 100 meters from the water body. This indicates that there is not a good safety distance between fields and water points, which would increase the risk of water contamination by different transfer mechanisms. Furthermore, between the field and the water body, buffer zone are absent $(78 \%)$ or is devoid of vegetation $(22 \%)$. Management of empty pesticide packaging remains problematic. The majority of producers (54\%) abandon them in the field. This mismanagement of empty packaging is one of the threatening practices commonly reported in producer surveys [22, 27-29]. As abandonment in the field, burial or incineration, these practices generate risks for the environment and human health. It is difficult, if not impossible, to clean the 
container of traces of pesticides.

Overall, vegetable producers followed a number of pest control practices by variety of chemical pesticides to control pest infestation and minimize crop losses. As previously reported by Jeyanthi and Kombairaju [5], the lesson that emerging from the results of the study are that pesticides were used by farmers without taken into account pest ecology, economic injury level, types of pesticides to control specific insect pests, their quantities and methods of application. The consequences of these inappropriate practices are environmental contamination and effects on human health and biodiversity. Once introduced into the environment through their multiple use, pesticides become distributed amoung water, air, soil, and biota (living organisms) by physical processes such as sedimentation, adsorption, and volatilization. The fraction of the chemical that will move into each compartment is governed by the physico-chemical properties of that chemical [17]. Some of these physico-chemical properties were analyzed and discussed below.

Table 4. List of pesticides recorded during the survey.

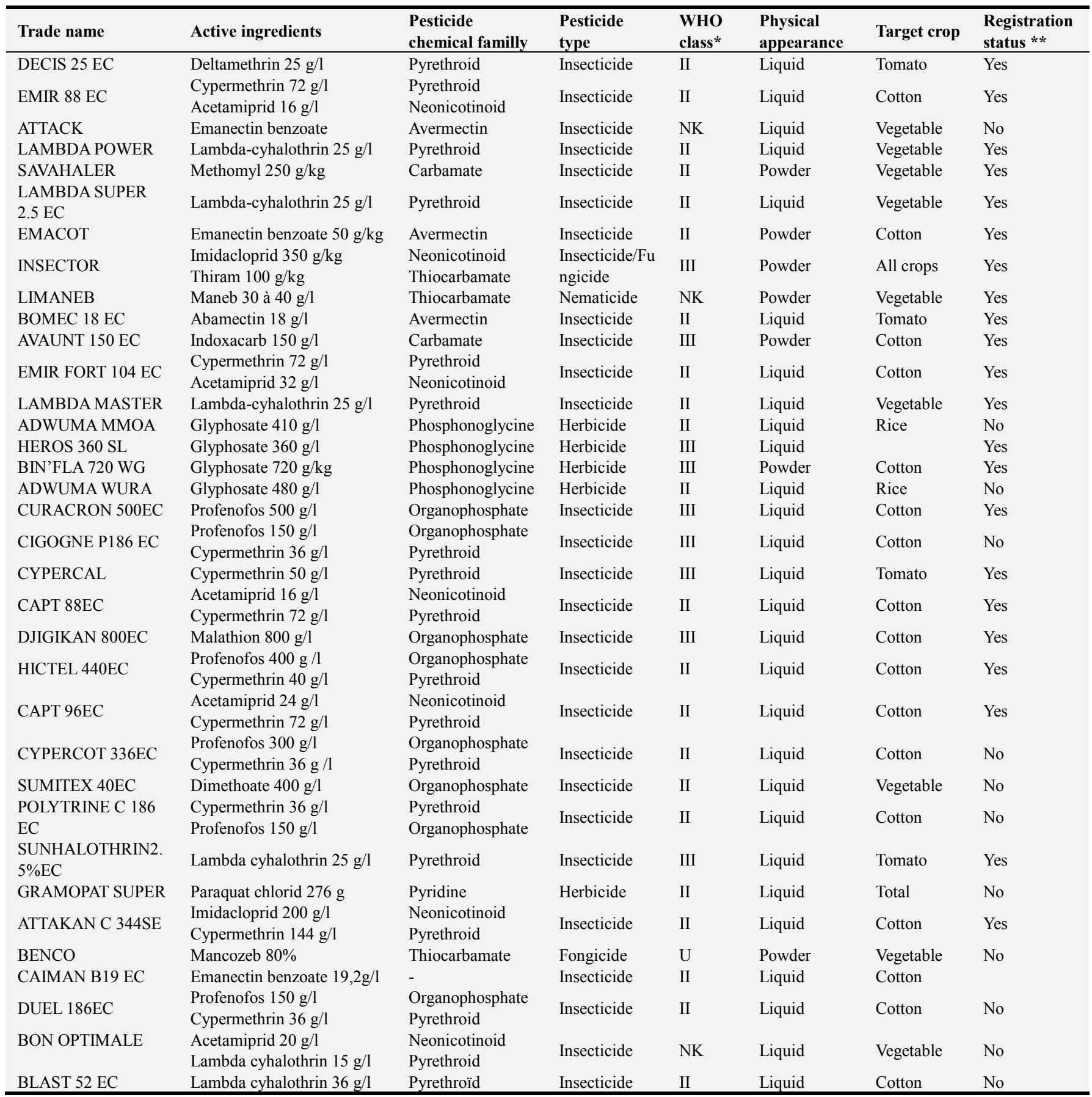

*II - moderately hazardous; III - slightly hazardous; U - unlikely to present acute hazard in normal use; - not listed.

**Sahelian Committee of Pesticides. 


\subsection{Analysis of Physico-chemical Properties of the Active Ingredients}

Table 5. Pesticide use practices by vegetable production farmers in Ouagadougou town.

\begin{tabular}{|c|c|c|c|}
\hline Practices & & $\mathbf{N}(\mathbf{n}=\mathbf{8 8})$ & $\%$ \\
\hline \multicolumn{4}{|c|}{ Frequency of recourse to pesticides } \\
\hline & A treatment every four days & 8 & 9 \\
\hline & Two treatment every week & 3 & 3 \\
\hline & A treatment every week & 77 & 88 \\
\hline \multicolumn{4}{|c|}{ Pesticide sources } \\
\hline & Market & 40 & 46 \\
\hline & Retailer & 33 & 37 \\
\hline & Shopkeeper & 11 & 12 \\
\hline \multicolumn{4}{|c|}{ Instruments for pesticides application } \\
\hline & Watering can & 2 & 2 \\
\hline & Bucket* & 10 & 12 \\
\hline & Knapsack sprayers & 75 & 86 \\
\hline \multicolumn{4}{|c|}{ Water source for crops irrigation } \\
\hline & Well & 52 & 59 \\
\hline & Dam & 61 & 69 \\
\hline & $\leq 10$ & 30 & 34 \\
\hline & 10 to 50 & 35 & 40 \\
\hline & 50 to 100 & 13 & 15 \\
\hline & $>100$ & 10 & 11 \\
\hline \multicolumn{4}{|c|}{ Instruments for crops irrigation } \\
\hline & Bucket & 2 & 2 \\
\hline & Watering can & 43 & 49 \\
\hline & Motor-pump & 29 & 33 \\
\hline \multicolumn{4}{|c|}{ Instrument of concentrated formulation measuring } \\
\hline & Pesticide bottle cap & 73 & 83 \\
\hline & Bucket & 11 & 12 \\
\hline & Bottle & 4 & 5 \\
\hline \multicolumn{4}{|c|}{ Pesticide packaging management** } \\
\hline & Abandonment in the field & 54 & 61 \\
\hline & Burying in the ground & 24 & 28 \\
\hline & Farmers washing their EPI & 60 & 68 \\
\hline & Washing in the field & 43 & 49 \\
\hline & Washing in the dam & 8 & 9 \\
\hline \multicolumn{4}{|c|}{ Compliance with pre-harvesting interval } \\
\hline & 7 days & 45 & 51 \\
\hline & 14 days & 27 & 31 \\
\hline & 21 days & 7 & 8 \\
\hline & 30 days & 9 & 11 \\
\hline \multicolumn{4}{|c|}{ Weather conditions taken into account when applying pesticides $(n=31)$} \\
\hline & Wind & 7 & 8 \\
\hline & Rain & 1 & 1 \\
\hline & Sunshine & 23 & 26 \\
\hline \multicolumn{4}{|c|}{ Soil nature $(n=43)$} \\
\hline & Clay soil, & 22 & 25 \\
\hline & Sandy soil & 4 & 4 \\
\hline & Sumus soil & 17 & 20 \\
\hline \multicolumn{4}{|c|}{ Presence of buffer zone } \\
\hline & Yes & 19 & 22 \\
\hline & No & 69 & 78 \\
\hline
\end{tabular}

** A practice doesn't exclude the others ones.

\subsection{Water Contamination Potential}

In this study, the Goss Algorithm Method was used for surface water contamination assessment. This method distinguishes the transport potential of pesticides in dissolved form or in form adsorbed to soil particles. Under both assumptions, the assessment of transport potential to surface water yielded the results displayed in table 6 . For the transport in dissolved form, seven and eight pesticides have low and medium transport potential respectively. Two have high potential (imidacloprid and thiram). Admitting transport under adsorbed form, eight and four pesticides have respectively low and medium transport potential. Five (deltamethrin, 
emanectin benzoate, indoxacarb, lambda-cyhalothrin, and paraquat chloride) have high potential.

The two last columns of Table 6 display the value of the GUS index for each pesticide and its interpretation. Regarding the GUS indexes in this table, nine pesticides were classified as having "Very low" leaching potential. Six pesticides have low leaching potential. Soarez et al. [20] are found that most of active ingredients $(52.73 \%)$ listed in a previous study they conducted were classified as having low leaching potential. In the present study, one pesticide has medium leaching potential (methomyl) and one also has high leaching potential (imidacloprid).

The models give a good prediction of environmental contamination, and the results corroborate the analysis data. Interestingly, previous work reported the presence of pesticide residues in both ground and surface water in vegetable growing areas $[32,28]$. In addition, the use of models lets acquisition of complementary data to those of field measurements, and helps to identify the contamination sources or to implement mitigation measures. However, in addition to the intrinsic properties of pesticides that allow estimate the potential for contamination of surface water, some practices of producers in the field can be factors of exacerbation of the phenomenon. Indeed, the absence of buffer zone, using sprinklers for pesticide application and watering practices can increase transport of pesticides to surface water, either in pesticides dissolved form or in its form associated to soil particles. Also, soil characteristics as its texture can affect chemical movement. Soil texture is an indication of the relative proportions of sand, silt, and clay in the soil. Pesticides tend to be adsorbed mostly on clay and organic matter. The higher the clay content, the greater the number of binding sites for pesticide retention [31].

Table 6. Pesticides physico-chemical properties and water contamination potential.

\begin{tabular}{|c|c|c|c|c|c|c|c|c|}
\hline \multirow{2}{*}{ Pesticides } & \multirow{2}{*}{$\begin{array}{l}\text { Solubility } \\
(\mathrm{mg} / \mathrm{l})\end{array}$} & \multirow{2}{*}{$\mathbf{D T}_{50}$} & \multirow{2}{*}{ Koc } & \multirow{2}{*}{$\log K_{o c}$} & \multicolumn{2}{|l|}{ Goss algorythm } & \multicolumn{2}{|c|}{ GUS index } \\
\hline & & & & & Goss (dissolved) & Goss (adsorbed) & GUS & GUS-based classification \\
\hline Abamectin & 0.020 & 25.3 & 23,103 & 1 & Low & Medium & 0.25 & Low \\
\hline Acetamiprid & 2950 & 1.6 & 200 & 2 & Medium & Low & 0.40 & Low \\
\hline Cypermethrin & 0.009 & 22.1 & 307558 & 5 & Low & Medium & -2.00 & Very low \\
\hline Deltamethrin & 0,0002 & 58.2 & 10240000 & 7 & Low & High & -4.37 & Very low \\
\hline Dimethoate & 25900 & 2.5 & 50 & 2 & Medium & Low & 1.01 & Low \\
\hline Emanectin benzoate & 24.0 & 300 & 377000 & 6 & Low & High & -1.63 & Very low \\
\hline Imidacloprid & 610 & 191 & 255 & 2 & High & Medium & 3.74 & High \\
\hline Indoxacarb & 0.2 & 113.2 & 4483 & 4 & Medium & High & 0.72 & Low \\
\hline Lambda-cyhalothrin & 0.005 & 175 & 283707 & 5 & Low & High & -3.28 & Very low \\
\hline Malathion & 148 & 0.17 & 1800 & 3 & Low & Low & -1.28 & Very low \\
\hline Mancozeb & 6.2 & 0.05 & 998 & 3 & Medium & Low & -1.45 & Very low \\
\hline Maneb & 178 & 1 & 2000 & 3 & Medium & Low & -0.88 & Very low \\
\hline Methomyl & 55000 & 7 & 72 & 2 & Medium & Low & 2.19 & Medium \\
\hline Profenofos & 28 & 7 & 2016 & 3 & Medium & Medium & 0.59 & Low \\
\hline Thiram & 18 & 4.89 & 676 & 3 & High & Low & 0.01 & Low \\
\hline
\end{tabular}

\section{Conclusion}

The environmental risk assessment of pesticides is a growing issue, particularly for the protection of the environment, and requires evaluation methods that include different types of impacts. This work made it possible to observe the different modes of transport, storage, preparation and application of pesticides in vegetable farmers and to highlight the different practices and risk behavior of producers when using pesticides. The results of the survey on the knowledge and use of pesticides around water bodies are very worrying. The Goss and GUS indexes can be used for the development of tool to predict water contamination by pesticide in pest management by vegetable farmers. This could contribute to the reinforcement of pesticide policy for advance their health, environmental and economic consequences.

\section{References}

[1] Dias JS (2011) World importance, marketing and trading of vegetables. Acta Hortic 921: 153-70.
[2] Ministère de l'agriculture, de l'hydraulique et des ressources halieutiques (2007) Analyse de la filière maraichage au Burkina Faso. Ouagadougou, Burkina Faso, 233.

[3] Kêdowide CMG, Sedogo MP, Cisse G (2010) Dynamique spatio temporelle de 1' agriculture urbaine à Ouagadougou: Cas du Maraîchage comme une activité montante de stratégie de survie. VertigO - la revue électronique en sciences de l'environnement. Volume 10 numéro 2.

[4] Bon H, Huat J, Parrot L, Sinzogan A, Martin T, Malézieux E, et al. (2014) Pesticide risks from fruit and vegetable pest management by small farmers in sub-Saharan Africa. A review. Agron Sustain Dev 34 (4): 723-36.

[5] Jeyanthi H, Kombairaju S (2005) Pesticide Use in Vegetable Crops: Frequency, Intensity and Determinant Factors 18: 209-21.

[6] Naré WAR, Savadogo PW, Gnankambary Z, Nacro HB, Sedogo MP (2015) Analyzing Risks Related to the Use of Pesticides in Vegetable Gardens in Burkina Faso. Agric For Fish 4 (4): 165.

[7] Son D, Somda I, Legreve A, Schiffers B (2017) Pratiques phytosanitaires des producteurs de tomates du Burkina Faso et risques pour la santé et 1 ' environnement Cah. Agric. 26: 25005. 
[8] Ecobichon DJ (2001) Pesticide use in developing countries. Toxicology 160 (1-3): 27-33.

[9] Jallow MFA, Awadh DG, Albaho MS, Devi VY, Thomas BM (2017) Pesticide knowledge and safety practices among farm workers in Kuwait: Results of a survey. Int. J. Environ. Res. Public Health 14, 340.

[10] Ilboudo S, Toe AM, Ouedraogo R, Ouedraogo M, Guissou IP (2014) Ecological Risk Assessment of Pesticide Residues in Water from Desert Locust Area in Burkina Faso. Res J Environ Earth Sci 6 (4): 227-32.

[11] Toe AM, Ouedraogo M, Ouedraogo R, Ilboudo S, Guissou PI (2013) Pilot study on agricultural pesticide poisoning in Burkina Faso. Interdiscip Toxicol 6 (4): 185-91.

[12] Kabore B, Kam S, Ouedraogo GWP, Bathiebo DJ (2017) Etude de l'évolution climatique au Burkina Faso de 1983 a 2012 : cas des villes de Ouagadougou et Dori Arabian Journal of Earth Sciences 4 (2): 70-80.

[13] Bambara D, Sawadogo J, Bilgo A, Hien E, Masse D (2019) Monitoring of Composting Temperature and Assessment of Heavy Metals Content of Ouagadougou's Urban Waste Composts. J Agric Environ Sci 8 (1): 72-81.

[14] Ouattara A, Some L (2009) La croissance urbaine au Burkina Faso. Ouagadougou, Burkina Faso, 29. Available from: http://www.insd.bf/fr/IMG/pdf/Theme9-Croissance_urbaine.p df.

[15] Nabie A (2018) Analyse des pratiques phytosanitaires et des facteurs d'adoption de la gestion intégrée des nuisibles en production maraîchère en milieu urbain et périurbain au Burkina Faso : Cas de la ville de Ouagadougou. Gembloux Agro-Bio Tech, Liège, Belgique, 257. http://hdl.handle.net/2268.2/5071.

[16] Nguyn TM, Thanh NT, Havukainen J, Hannaway DB (2018) Pesticide use in vegetable production: A survey of vietnamese farmers' knowledge. Plant Prot Sci (4): 203-14.

[17] Linde CD (1994) Physico-Chemical Properties and Environmental Fate of Pesticides. California, USA, 56.

[18] Goss DW (1992) Screening Procedure for Soils and Pesticides for Potential Water Quality Impacts. Weed Technology 6 (3): 701-8.

[19] Kortekamp A (2011) Herbicides and Environment. India, 760. www.intechopen.com.

[20] Soares AFS, Leão MMD, Vianna Neto MR, Oliveira SMAC (2012) Risk estimate of water contamination by pesticides used in coffee crops. Rev Bras Eng Agric e Ambient 16 (4): 425-32.
[21] Gustafson DI (1989) Groundwater ubiquity score: A simple method for assessing pesticide leachability. Environ Toxicol Chem 8 (4): 339-57.

[22] Oluwole O, Cheke RA (2009) Health and environmental impacts of pesticide use practices: A case study of farmers in Ekiti State, Nigeria. Int J Agric Sustain 7 (3): 153-63.

[23] Adjrah Y, Dovlo A, Karou SD, Eklu-gadegbeku K, Agbonon A, de Souza C, Gbeassor M (2013) Survey of pesticide application on vegetables in the Littoral area of Togo. Annals of Agricultural and Environmental Medicine 20 (4): 715-20.

[24] Ngowi AVF, Mbise TJ, Ijani ASM, London L, Ajayi OC (2007) Pesticides use by smallholder farmers in vegetable production in Northern Tanzania. Crop Prot 26 (11): 1617-1624.

[25] Williamson S, Ball A, Pretty J (2008) Trends in pesticide use and drivers for safer pest management in four African countries. Crop Prot 27 (10): 1327-34.

[26] Tarnagda B, Tankoano A, Tapsoba F, Sourabié PB, Abdoullahi HO, Djbrine A et al. (2017) Évaluation des pratiques agricoles des légumes feuilles: le cas des utilisations des pesticides et des intrants chimiques sur les sites maraîchers de Ouagadougou, Burkina Faso. Journal of Applied Biosciences 117: 11658-11668.

[27] Ajayi OC, Akinnifesi FK, Programme SA, Box PO (2007) Farmers' understanding of pesticide safety labels and field spraying practices: a case study of cotton farmers in northern Côte d'Ivoire 2: 204-10.

[28] Gouda A-I, Imorou Toko I, Salami S-D, Richert M, Scippo M-L, Kestemont P, et al. (2018) Pratiques phytosanitaires et niveau d'exposition aux pesticides des producteurs de coton du nord du Bénin. Cah Agric 27 (6): 65002.

[29] Rotterdam Convention/FAO (2010) Pilot Study on Agricultural Pesticide Poisoning in Burkina Faso. Final report, Bobo Dioulasso, Burkina Faso, 102.

[30] Kellogg RL, Nehring RF, Grube A, Goss DW, Plotkin S (2002) Environmental Indicators of Pesticide Leaching and Runoff from Farm Fields. Agric Product 213-56.

[31] Thakur S, Gulati K, Jindal T (2015) Groundwater contamination through pesticide usage in vegetable growing areas of Delhi 394-7.

[32] Kanda M, Djaneye-Boundjou B, Wala K, Gnandi K, Batawila K, Sanni A, Akpagana K (2012) Assessment of pesticide residues and trace element contamination in market gardens of Togo. African J Environ Sci Technol 6 (10): 380-90. 